\title{
Innovation measurement: An extensive literature analysis
}

\author{
Katarina Janoskova ${ }^{1, *}$, Pavol $\mathrm{Kral}^{2}$ \\ 1,2 University of Zilina, Faculty of Operation and Economics of Transport and Communications, \\ Univerzitna 1, 01026 Zilina, Slovakia
}

\begin{abstract}
Research background: There is no doubt that innovation is an important source of a company's competitiveness, but it is very difficult to measure the extent to which it contributes to the growth of competitiveness. Opponents of measuring innovation argue that measuring innovation is a measurement of the immeasurable. How to measure innovations and is it possible to measure innovations, is a question constantly posed by academics, managers, and economists all over the world. To find answer to these questions, this review article analyses scientific publications on innovation measurement published between 1968 and 2021.

Purpose of the article: The main purpose of this article is to increase the understanding of the metrics landscape and to identify differences in the methods used in the past and present with emphasis on identification of statistical and econometric methods used to study innovation.

Methods: To achieve the purpose of the article, literature review as a method of qualitative research was used. Data for literature review were gained from the Web of Science database.

Findings \& Value added: The analysis finds several metrics that can be used for evaluation of company's innovation. The results can helps managers, academics, and economists to better understand the innovation measurement..
\end{abstract}

Keywords: innovation potential, innovation capacity, innovation measurement

JEL Classification: $O 30,032,039$

\footnotetext{
* Corresponding author: katarina.janoskova@ffpedas.uniza.sk
} 


\section{Introduction}

Globalization increases competition and competition contributes to the increase in innovation. Globalization brings new opportunities (Vagner, 2016) and innovation is the way to take advantage of these opportunities. Innovation are characterized by great economic value (Gavurova et al., 2021).

Given today's competitive business environment, innovation has become a critical function. In order to manage innovation effectively, it needs to be measured. However, measuring innovation has proved to be very challenging. (Manoochehri, 2010).

If any phenomenon cannot be measured, it is not even possible to control it properly. For the effective management of any phenomenon and activities in economic entities, it is therefore necessary to ensure a suitable way of measuring them. A common question about innovation is: "Is it possible to measure innovation?" Some doubt it. Due to the scope, complexity and intangibility of innovation activities, their measurement is quite demanding. Some managers refer to measuring innovation as "measuring the immeasurable". The essence of innovation is novelty, so it is logical that some innovation will not be possible to measure through a pre-set measurement scheme. It may even be that the most effective innovation will be one that change the scheme of things so much that the old measurement metric becomes obsolete and unusable (Shapiro, 2006).

Opponents of measuring innovation argue that measurement discourages managers from making breakthrough innovations (Criscuolo et al., 2017). Several studies have shown that in many cases measurement does not support but rather hinders the innovation process.

Opponents of measuring innovation justify their opinion by saying that innovation is a very broad and ambiguous term. Innovation is not a recurring activity. Every innovation is different and therefore it is not possible to have a metric that can measure every single innovation to take into account its entire specific. Innovation activities involve such a wide range of activities that it is almost unrealistic to find metrics that can measure them reliability and comprehensively. Scepticism about measuring innovation in many cases stems from a vaguely defined object of measurement. Therefore, a clear classification of metrics to measure innovation is necessary. Each view of innovations must correspond to the relevant metrics of their measurement. Therefore, it is important to know which area of innovation we want to measure, such as innovation performance (Durana et al., 2020), innovation potential, innovation capacity, etc. Different perceptions of innovation require the use of different metrics to measure them.

Based on the basic doctrine - Oslo Manual (2018) which is a document providing guidance for the collection and interpretation of innovation data in an effort to facilitate international comparability, innovation can be measured and should therefore be measured. The results of innovation measurements can help to better understand economic and social change assess the positive or negative impacts of innovation on social and economic objectives, and monitor and evaluate the effectiveness of policies.

The ability to measure and characterize an organization's innovative capabilities in essential for an entity to know its current status and how it should act to improve in the future (Fred-Ojala et al., 2018).

\section{Methods}

To achieve the purpose of the article, literature review as a method of qualitative research was used. A critical review was undertaken based on a systematic review methodology to aggregate evidence of innovation measurement. The goal of the review was to identify several area of innovation measurement and common indicators used in the process of 
measurement. Data for literature review were gained from the Web of Science database. The reviewing process include search and selection, reviewing and reporting of the results.

\section{Results and discussion}

It is important to realize that every innovation is different, so it is difficult to define a unified metric that can be used to evaluate and measure all innovations. It can be said that it is practically impossible. Therefore, metrics are generally adapted to the circumstances of the rated entity and simplifications often occur, without which the metrics would not be applicable. Innovation measurement metrics need to be designed to reflect the nature of the industry and market, business objectives and strategies, capabilities and strengths, access to innovation, etc.

Based on literature it is important to know which area of innovation we want to measure. Different perceptions of innovation require the use of different metrics to measure them. Our research was focused on the two main areas of innovation measurement:

- measurement of innovation potential

- measurement of innovation capacity

\subsection{Measuring innovation potential}

The practical aspect of the concept of innovation potential is reflected in the works of $P$. Drucker, in which he examines the sources of modern industrial development. He noted that innovation began with an analysis of existing potential in order to use it effectively (Valitov and Khakimov, 2015). Innovation potential is the ability of a company to use its own internal resources efficiently in the given circumstances in order to improve, manage or streamline a certain product or process. It represents the overall ability of the company (including its departments and components) to successfully, permanently implement the vision and allows it to respond flexibly to stimuli, create and develop activities with higher benefit.

Innovation potential measurement is very difficult. There are many approaches to measuring innovation potential. A common feature is that all authors consider innovation potential to be a set of several factors. For this reason, metrics of a company's innovation potential are usually in the nature of composite synthetic indicators. Based on the available domestic and foreign scientific literature, we compiled an overview of various components of innovation potential, which we divided into several types according to their content relatedness (Table 1).

Table 1. Components of innovation potential

\begin{tabular}{|l|l|l|}
\hline $\begin{array}{l}\text { Group of } \\
\text { components }\end{array}$ & Component of innovation potential & Author (year) \\
\hline Human resources & $\begin{array}{l}\text { Highly skilled workfoce } \\
\text { Creativity of employees and managers }\end{array}$ & Krayneva et al. (2017) \\
& Employee satisfaction & Koschatzsky et al. (2001) \\
& Employee motivation & Stanislawski and Lisowska \\
& Conflicts resolution in the workplace & (2015) \\
& Skills and competencies & Vacek et al. (2011) \\
& Meaningfulness of work & Kovac (2010) \\
& Open communication & Sabadka (2012) \\
& & Aiman-Smith (2005) \\
\hline $\begin{array}{l}\text { Technological } \\
\text { resources }\end{array}$ & Devices & Krayneva et al. (2017) \\
& Security through advanced technologies & Dzikowski (2012) \\
& & Stanislawski and Lisowska \\
& & (2015) \\
\hline
\end{tabular}




\begin{tabular}{|c|c|c|}
\hline $\begin{array}{l}\text { Financial } \\
\text { resources }\end{array}$ & $\begin{array}{l}\text { Own resources } \\
\text { Grants } \\
\text { Loans }\end{array}$ & $\begin{array}{l}\text { Krayneva et al. (2017) } \\
\text { Dzikowski (2012) } \\
\text { Stanislawski and Lisowska } \\
\text { (2015) } \\
\text { Koschatzsky et al. (2001) } \\
\text { Bistrova et al. (2017) }\end{array}$ \\
\hline $\begin{array}{l}\text { Organizational } \\
\text { resources }\end{array}$ & $\begin{array}{l}\text { Strategy and planning } \\
\text { Product, production and organizational } \\
\text { ability } \\
\text { Operational skills } \\
\text { Transaction capabilities } \\
\text { Managerial skills } \\
\text { Conceptual activiteis }\end{array}$ & $\begin{array}{l}\text { Dzikowski (2012) } \\
\text { Stanislawski and Lisowska } \\
\text { (2015) } \\
\text { Vacek et al. (2011) } \\
\text { Zawislak et al. (2012) } \\
\text { Aiman-Smith (2005) }\end{array}$ \\
\hline Intangible assets & $\begin{array}{l}\text { Share of intangible assets in total assets } \\
\text { Intellectual Property } \\
\text { Number of patents or patent applications } \\
\text { The effectiveness of patents } \\
\text { Knowledge } \\
\text { Purchase patents, licenses and knowledge } \\
\text { Sales of patents, licenses and knowledge } \\
\text { Learning organization }\end{array}$ & $\begin{array}{l}\text { Krayneva et al. (2017) } \\
\text { Dzikowski (2012) } \\
\text { Stanislawski and Lisowska } \\
\text { (2015) } \\
\text { Bistrova et al. (2017) } \\
\text { Aiman-Smith (2005) }\end{array}$ \\
\hline $\begin{array}{l}\text { Research \& } \\
\text { Development }\end{array}$ & $\begin{array}{l}\text { Own company research and development } \\
\text { Research and development expenditure } \\
\text { Research and development workers } \\
\text { Ability of technological development } \\
\text { Development cycle } \\
\text { Research and development results }\end{array}$ & $\begin{array}{l}\text { Stanislawski a ndLisowska } \\
(2015) \\
\text { Koschatzsky et al. (2001) } \\
\text { Zawislak et al. (2012) } \\
\text { Kovac (2010) } \\
\text { Sabadka (2012) }\end{array}$ \\
\hline New products & $\begin{array}{l}\text { Number of new products } \\
\text { Sales of new products for the last three } \\
\text { years } \\
\text { Technological level of new products } \\
\text { Competitive level of new products } \\
\text { Level of quality and reliability of new } \\
\text { products } \\
\text { Payback period }\end{array}$ & $\begin{array}{l}\text { Bistrova et al. (2017) } \\
\text { Kovac (2010) } \\
\text { Sabadka (2012) }\end{array}$ \\
\hline Marketing & $\begin{array}{l}\text { Market position } \\
\text { Relationships with customers and suppliers } \\
\text { Marketing and market observation } \\
\text { Customer orientation }\end{array}$ & $\begin{array}{l}\text { Vacek et al. (2011) } \\
\text { Dzikowski (2012) } \\
\text { Stanislawski and Lisowska } \\
\text { (2015) } \\
\text { Aiman-Smith (2005) } \\
\end{array}$ \\
\hline Support & $\begin{array}{l}\text { Government support } \\
\text { Support for business environment } \\
\text { institutions } \\
\text { Innovation partnerships and support } \\
\text { systems }\end{array}$ & $\begin{array}{l}\text { Stanislawski and Lisowska } \\
(2015) \\
\text { Kovac (2010) } \\
\text { Sabadka (2012) }\end{array}$ \\
\hline
\end{tabular}

Source: own processing according to the several authors (in table)

Many researchers argue that innovation potential (determined by $R \& D$ expenditures or intangible assets) correlates positively with market value and financial performance (Bistrova et al., 2017). The vast majority of studies created by academics agree that investing in innovation is most likely to increase the company's profitability and value. Innovation is usually determined by $R \& D$ expenditures, by launching a new product, or through intangible assets. 


\subsection{Measuring innovation capacity}

Innovation capacity significantly affects the competitiveness of the company. Measuring innovation capacity is therefore one of the innovation metrics used by academic, business managers and innovation policy makers.

Innovation capacity is understood in terms of innovation performance. It is a current product of the innovation process as well as a combination of resources and efficiency (Vasin and Gamiduelleava, 2015).

Innovation capacity is not developed in the literature at the same level as innovation potential and if we look at its structure (Table 2) based on the approaches of selected authors, it is in many cases identical with the structure of innovation potential.

Table 2. Components of innovation capacity

\begin{tabular}{|l|l|}
\hline Components of innovation capacity & Author (year) \\
\hline Organizational culture & Koc (2007) \\
Learning organization & \\
Human resource & \\
Knenerating ideas & \\
Technology focus & \\
Cross - sectional integration & \\
Dissemination of knowledge & \\
\hline Internal resources: investment in research and development \\
Skills: dynamic skills and knowledge utilization, interaction skills, \\
risk propensity, customer orientation and market knowledge, and \\
management skills to seize opportunities quickly and implement \\
change) & \\
External input gained through networks: knowledge creation, & \\
sourcing and benefits gained through collaboration & \\
\hline Design & \\
Project management & \\
Integrated strategy & \\
Project portfolio management & \\
Appropriate definition of the organization & Boly et al. (2014) \\
Improving the innovation process & \\
Competence management & \\
Moral support & \\
Knowledge management \\
Competitive technological intelligence \\
Network management \\
Collective learning \\
Idea creation / creativity \\
Research and development activities \\
Customer relationship management & \\
\hline
\end{tabular}

Source: own processing according to Koc (2007); Forsman (2011); Boly et al. (2014).

\section{Conclusion}

Less is sometimes more. Given the scale of innovation activities, it is necessary to use a sufficient number of metrics, but it is not appropriate for a company to "fall into the trap" of measurement and also measure irrelevant and inappropriate factors. Business leaders are often overwhelmed by different metrics. The main problem is if businesses have too many 
metrics and try to measure everything according to different criteria. Too many metrics lead to excessive activity that provides low value and often leads to conflicting behaviour.

Salomon (2016) states that a good metric for measuring innovation should meet several characteristics: i) comparison; ii) goal setting; iii) identify the weaknesses; iv) include available data; v) include current inputs; vi) measure innovation in all dimensions.

\section{Acknowledgements}

The contribution is an output of the project VEGA 1/0619/20 Fundamental research of quantitative and qualitative determinants of enterprise innovation potential and innovation performance in relation to increasing its competitiveness.

\section{References}

1. Aiman-Smith, L., Goodrich, N., Roberts, D., \& Scinta, J. (2005). Assessing Your Organization's Potential for Value Innovation. Research Technology Management Journal, March-April 2005, 37-42.

2. Bistrova, J., Lace, N., Tamošiuniene, R., \& Kozlovskis, K. (2017). Does firm's higher innovation potential lead to its superior financial performance? Case of CEE countries. Technological and Economic Development of Economy, 23(2), 375-391.

3. Boly, V., Morel, L., Assielou, N’D., G., \& Camargo, M. (2014). Evaluating innovative processes in french firms: Methodological proposition for firm innovation capacity evaluation. Research Policy, 43(3), 608-622.

4. Criscuolo, P., Dahlander, L., Grohsjean, T., \& Salter, A. (2017). Evaluating novelty: The role of panels in the selection of R\&D projects. Academy of Management Journal, 60(2), 433-460

5. Durana, P., Zauskova, A., Vagner, L., Zadnanova, S. (2020). Earnings Drivers of Slovak Manufacturers: Efficiency Assessment of Innovation Management. Applied Science Basel, 10(12), 4251.

6. Dzikowski, P. (2012). Developing the innovation potential of a medium sized family business functioning in a global supply chain. Management, 16(1), 101-118

7. Forsman, H. (2011). Innovation capacity and innovation development in small enterprises. A comparison between the manufacturing and service sectors. Research Policy, 40(5), 739-750.

8. Fred-Ojala, A., Sidhu, I., Johnsson, Ch., \& Suoranta, M. (2018). The Berkeley Innovation Index: A Quantitative Approach to Measure, Track and Forecast Innovation Capability Within Individuals and Organizations. International Conference on Mobile and Wireless Technology (ICMWT 2018), 311-320.

9. Gavurova, B., Belas, J., Valaskova, K., Rigelsky, M., \& Ivankova, V. (2021). Relations between infrastructure innovations and tourism spending in developed countries: a macroeconomic perspective. Technological and economic development of economy, 27(5), 1072-1094.

10. Koc, T. (2007). Organizational determinants of innovation capacity in software companies. Computers \& Industrial Engineering, 53 (3), 373-385.

11. Koschatzky, K., Bross, U., \& Stanovnik, P. (2001). Development and innovation potential in the Slovene manufacturing industry: analysis of an industrial innovation survey. Technovation, 21, 311-324. 
12. Kovac, M. (2010). Aplikácia metrík pre stimulovanie inovácií. Transfer inovácií, 16, 811.

13. Krayneva, R., Bugaev, A., Zhuravleva, T., \& Vojtovič, S. (2017). Management and promotion of economic innovation potential. Journal of International Studies, 10(1), 146-158.

14. Manoochehri, G. (2010). Measuring Innovation: Challenges and Best Practices. California Journal of Operations Management, 8(1), 67-73.

15. Oslo Manual 2018 (2018). 4th Edition. OECD.

16. Sabadka, D. (2012). Innovation Potential Metrics. International Journal of Engineering, $10(3), 449-455$.

17. Shapiro, A. R. (2006). Measuring Innovation: Beyond Revenue from New Products. Research Technology Management, 49(6), 42-51.

18. Solomon, Y. (2016). Measuring Innovation, Part 2/3: The Criteria for a Good Innovation Index. Retrieved from: https://www.innovationexcellence.com/ blog/2016/05/10/measuring-innovation-part-23-the-criteria-for-a-good-innovationindex/

19. Stanislawski, R., \& Lisowska, R. (2015). The relationship between innovation openness (open innovation) and the innovation potential of SMEs. Procedia Economics and Finance, 23, 1521-1526.

20. Vacek, J., Vacik, E., Skalicky, J. a Slechtova, Y. (2001). Map of the company innovation potential. Project Leondardo da Vinci. U-SME Innovation. Retrieved from: http://www.kip.zcu.cz/USME/ass_SME.doc

21. Vagner, L. (2016). Controlling as a competitiveness tool in the global market. 16th International Scientific Conference on Globalization and its Socio-Economic Consequences, 2260-2266.

22. Valitov, S. M., \& Khakimov, A. Kh. (2015). Innovative potential as a framework of innovative strategy for enterprise development. Procedia Economics and Finance, 24, 716-721.

23. Vasin, S. M., \& Gamidullaeva, L. A. (2015). Methodical Approach and Tools to Improve the Efficiency of Managing of the Innovation Potential in the Context of Economic Globalization. Review of European Studies, 7(3), 124-139.

24. Zawislak, P. A., Alves, A. Ch., Tello-Gamarra, J., Barbieux, D., \& Reichert, F. M. (2012). Innovation Capability: From Technology Development to Transaction Capability. Journal of Technology Management \& Innovation, 7(2), 14-27. 